УДК 378.147

DOI:

Олена Писаревська, асистент кафедри франиузької філологї Львівського національного університету імені Івана Франка

\title{
МЕТОДОЛОГІЧНІ АСПЕКТИ ФОРМУ ВАННЯ ПРОФЕСІЙНОЇ КОМПЕТЕНТНОСТІ МАЙБУТНІХ ЮРИСТІВ В УНІВЕРСИТЕТАХ ФРАНЦІї
}

У статті розглянуто методологічні аспекти формування професійної компетентності майбутніх юристів в університетах Франції. Проаналізовано місце компетентнісного підходу у системі сучасноі франиузької вищої освіти. Розглянуто поняття “компетентності” та “компетенції” у педагогічних дослідженнях. Визначено поняття "професійної компетентності юриста" та проаналізовано його зміст та структуру. Окреслено перелік компетенцій, що складають професійну компетентність сучасного франиузького юриста.

Ключові слова: вищза юридична освіта у Франиії; компетенція; компетентність; професійна компетентність юриста; методологічні аспекти.

Jim. 12.

Olena Pysarevska, Lecturer of the French Philology Department of the Ivan Franko National University of Lviv

\section{METHODOLOGICALASPECTS OF FORMING THE PROFESSIONAL COMPETENCE OF FUTURE LAWYERS AT THE UNIVERSITIES OF FRANCE}

The article sets to explore the methodological aspects of forming the professional competence of future lawyers at the universities of France. It analyses the role of the competence-based approach in the system of modern French higher education and considers the concepts "competence" and "competency" in pedagogical research. In addition, the paper researches the concept of professional competence in the context of higher legal education. The concept "professional competence of a lawyer" is defined and its content and structure are analysed. The changes that have taken place in recent years in the understanding of the professional competence of lawyers and the need for obtaining new types of competencies are considered. There is a list of competencies that constitute the professional competence of a modern French lawyer and the process of its formation in the course of studying in three cycles at universities, License (Bachelor), Master (Master), Doctorat (PhD) or in specialized educational institutions. The national educational framework of the bachelor's and master's degrees and the list of competencies required for obtaining these diplomas are analysed. This list contains, in particular, subject competencies, primarily in a major and related disciplines; language competencies, consisting of the ability to read, write and express verbally and in the written form in at least one foreign language; transversal competencies, such as the ability to analyse and synthesize, to form oral and written expression, to perform individual or collective work, to identify and use necessary information and documentary resources; and preprofessional competencies based on knowledge in the fields related to learning and the ability to create an individual professional student project and to use the acquired knowledge and skills in a professional context. The paper considers their compliance with the requirements of the professional environment and the connection with the professional context. The difference between the competencies that are formed at the educational levels Licence (Bachelor) and Master and their interconnection is researched.

Keywords: higher legal education of France; competency; competence; professional competence of a lawyer; methodological aspects.

П остановка проблеми. Актуальність даної статі обумовлена вимогами сучасних освітніх реалій, оскільки дослідження процесів формування професійної компетентності майбутніх юристів в університетах Франції сприятиме успішному формуванню професійної компетентності майбутніх фахівців у галузі міжнародного права в українських закладах вищої освіти за європейськими та світовими стандартами.

Аналіз останніх досліджень і публікацій. Аспектами формування професійної компетентності фахівців різних спеціальностей науковці займались у попередні роки. Висвітлення даної проблеми знайшло відображення у працях Г. Ле Бофера, Б. Дондеро, Ж. Бугена та Л. Жюльєна, Ф. Тільман. Компетентністний підхід у вищій освіті досліджували Дж. Равен, О. Хуторской, І. Зимняя, В.Байденко, світовий досвід компетентністного підходу висвітлено унаукових працях Л. Антонюк, Н. Василькової, а його онтологію та епістемологію - у дослідженнях О. Субетто. М. Оліяр досліджує теоретичні аспекти феномена “комунікативно-стратегічна компетентність", 


\section{МЕТОДОЛОГІНН АСПЕКТИ ФОРМУВАННЯПРОФЕСИЙНОӤ КОМПЕТЕНТНОСТІ МАЙБУТНІХ ЮРИСТІВ В УНІВЕРСИТЕТАХ ФРАНЦІЇ}

Педагогічними аспектами вищої юридичної освіти та процесом ії глобалізації цікавляться А. де Люже, М.Ф. Лонжу, С. Ларонд Клерак, Д. Коровяковський.

Мета статті полягає у аналізі методологічних аспектів формування професійної компетентності майбутніх юристів в університетах Франції.

Виклад основного матеріалу. В основі сучасних світових тенденцій у сфері вищої освіти лежить компетентністний підхід, який розглядається як поняття і як системна концепція опису освіченості особистості людини, починаючи з 90-х років минулого століття під впливом ідей змінити модель освіти в Західній Європі та США взагалі й ідей Болонського процесу зокрема [6, 5]. Цей підхід пов'язаний із змінами освітньої моделі Західної Свропи та США, Болонським процесом, ідеєю єдиного Європейського освітнього простору. Саме поняття “компетентність” стало невід'ємною складовою частиною педагогічних досліджень у всьому світі, зокрема після США, поняття "аpproche par compйtences" (APC), “компетентнісний підхід”, з'являється у роботах франкомовних дослідників із Квебеку, Швейцарії, Бельгії, Голландії і Франції. Протягом трьох останніх десятиліть компетентнісний підхід із акціональною перспективою укорінився і у системі вищої освіти Франції, відкривши можливість для нових педагогічних підходів, включно із галуззю професійної освіти. Результатом компетентністноорієнтованого підходу в освіті є сформований комплекс ключових компетентностей, які відображають рівень особистого та професійного розвитку особи та готовність до ефективної професійної діяльності.Навчання на основі компетентнісного підходу формує у студентів якості для реалізації професійної діяльності, які необхідні для ринку праці, а критерії та параметри оцінки результатів освіти уніфікуються і виражаються у термінах і результатах, які можуть бути інтерпретовані і враховані у будь-якому освітньому закладі будь-якої країни $[1,12]$.

Базовими поняттями компетентнісного підходу $\epsilon$ компетенція і компетентність. Ці поняття активно вивчаються у сучасній педагогічній науці, але єдності серед науковців щодо визначення немає. При всьому розмаїтті поглядів на сутність даної категорії, у більшості визначень наголошується на вмінні застосовувати в реальних ситуаціях набуті знання, спроможності, навички тощо $[1,5]$. На думку Дж. Равена, компетентність - це здатність людини до виконання конкретної дії в певній галузі діяльності, яка включає способи мислення, знання, навички та готовність бути відповідальним за свої вчинки $[7,5]$. За Я. Крупським, компетентність - рівень освіченості, що характеризується здатністю вирішувати завдання у різних сферах життєдіяльності на базі теоретичних знань $[4,7]$. За Національним освітнім глосарієм [3, 28], компетентність / компетентності (competence, competency / competences, competencies) - це динамічна комбінація знань, вмінь і практичних навичок, способів мислення, професійних, морально-етичних цінностей, яка визначає здатність особи успішно здійснювати професійну та подальшу навчальну діяльність і є результатом навчання на певному рівні вищої освіти.

Компетентності лежать в основі кваліфікації випускника. Компетентність (компетентості) розглядаються як набуті реалізаційні здатності особи до ефективної діяльності [3, 28 - 29]. Гі ле Бофер відокремлює “компетентність” професіонала, як його здатність керувати сукупністю професійних ситуацій, тобто діяти компетентно і ефективно, від “компетенції”, які потрібно комбінувати і активізувати, щоб керувати цими ситуаціями. Ці компетенції є частиною особистих ресурсів (знань, навичок, людських якостей, досвіду і походять із оточення особистості (сукупність даних, люди, які виступають ресурсом) [9, 31]. На його думку, професійна компетентність займає першочергове місце у потребах підприємств та індивідів. Професійна компетентність виступає ключовим ресурсом у набутті ефективності та основною перевагою у конкурентному середовищі. Капітал компетентностей $\epsilon$ необхідним, щоб якнайкраще керувати своєю професійною мобільністю та цінністю на ринку праці. Аналізуючи вищенаведені джерела, можемо стверджувати, що поняття “компетентність" i “компетенція” взаємопов'язані і близькі, але мають суттєві відмінності. Таким чином, на нашу думку “компетентність" - це те, що людина вміє і знає. “Компетенція" - коло прав та уповноважень, в межах яких людина повинна вміти і знати те, що $\epsilon$ необхідним, тобто це предметна область, у якій індивід добре орієнтується і виявляє здатність до здійснення діяльності.

На основі здійсненого аналізу [1; 5; 2] під професійною компетенцією юриста розуміємо сформованість цілісного комплексу знань, умінь та навиків, психологічних якостей та професійних можливостей, вміння використати ці знання, навички і досвід в конкретно даних умовах, досягнувши при цьому максимально позитивного результату. Вона передбачає поєднання здатності фахівця до творчого розв'язання проблем і наявність професійних умінь. Це також надання повноважень посадовій особі у певній юридичній галузі, яке є виправданим правомочністю 


\section{МЕТОДОЛОПІЧН АСПЕКТИ ФОРМУВАННЯПРОФЕСІЙНОЇ КОМПЕТЕНТНОСТІ МАЙБУТНІХ ЮРИСТІВ В УНІВЕРСИТЕТАХ ФРАНЦІЇ}

застосувати ці вміння, знання, досвід, навички, а також здатність найкращим чином виконувати ці повноваження. На думку К. Левітана, юридична освіта - це процес безперервного особистопрофесійного становлення юриста у соціокультурному розвиваючому просторі начального закладу, результатом якого $\epsilon$ досягнутий рівень професійної компетентності, що дозволяє якісно вирішувати професійні задачі [5, 236]. Професійна компетентність - це інтегративна якість особистості спеціаліста, що закінчив освіту певного ступеня, яка виявляється у його готовності та здатності до успішної професійної діяльності із урахуванням її соціальної важливості. Зміст і структура професійної компетентності багато в чому визначаються специфікою і структурою професійної діяльності. Отже, компетентний юрист - це фахівець, що розуміється на юриспруденції і має право, на основі спеціальних знань, вмінь, навичок, обов'язків та повноважень здійснювати юридичнудіяльність [5, 236]. С.Д. Гусарєв та О.Д. Тихомиров переконані, що професійна компетентність юриста - це властивість юридичної практичної діяльності, що $\epsilon$ похідною від компетентності, під якою, як правило розуміємо визначену чи закріплену законом, іншим нормативним актом сукупність професійних функцій, завдань, повноважень посадової особи або іншого суб' єкту професійної діяльності [2, 114]. Компетентність юриста означає наявність правових та інших спеціальних знань, навичок і умінь, професійного досвіду, які набуваються внаслідок професійної підготовки та здійснення професійної діяльності. Компетентне ведення юридичної справи складається із розслідування та аналізу фактичної інформації, правових елементів проблеми, застосування необхідних методів та процедур, адекватної підготовки, що відповідають стандартам професійної діяльності $[2,115]$. Сучасний юрист повинен знати законодавство, етичні та правові норми, бути здатним вести професійну діяльність в іншомовному середовищі, вміти організовувати свою роботу на науковій основі, володіти методиками збору, зберігання та обробки інформації, зокрема за допомоги комп'ютерних технологій, бути здатним поставити мету та окреслити задачу, пов'язану із реалізацією професійних функцій, бути готовим до співпраці із колегами у колективі, знати і вміти використовувати управлінські методи, вміти організовувати роботу підлеглих, знаходити управлінські рішення тощо. Сучасні французькі спеціалісти угалузі юридичної освіти в свою чергу виділяють чотири основні сфери застосування професійних компетенцій юристів: загально юридичні компетенції, бізнес-компетенції, поведінкові та цифрові компетенції $[10,10]$. У сфері загально юридичних компетенцій спостерігається розширення поля юридичної проблематики: поява нових галузей, як наприклад міжнародне право навколишнього середовища, право власності на інформацію та правовий захист баз даних, юридичний комплаєнс, та значне ускладнення робочих ситуацій. Все більш успішними стають останнім часом юридичні кабінети, працівники яких володіють специфічними компетентностями: ісламські фінанси, будівельне право, інтелектуальна власність, напротивагуколишніммультифункціональним установам.

На формування професійної компетентності юриста спрямований процес здобуття вищої юридичної освіти. Сучасна система вищої освіти у Франції характеризується різноманітністю навчальних закладів, організація навчання та умови прийому в яких не є однаковими $[8,96]$. У французьких вищих навчальних закладах навчання відбувається поетапно: Licence (бакалаврат), Master (Магістратура), Doctorat (аспірантура). Для кожного навчального рівня характерним є перелік компетентностей, що їх здобуде студент по завершенні цього рівня. Постанова Міністерства освіти Франції від 22 січня 2014 року встановлює національні освітні рамки для видачі дипломів рівня "Licence" [11]. Диплом освітнього рівня "Licence" підтверджує здобуття фундаменту знань та компетентностей у предметному та багатопредметному полі. Навчання на освітньому рівні "Licence" ознайомлює студента із процесом продукування знань, основними цілями і засобами їх досягнення у дослідженнях та науковими методами відповідної галузі знань. Освітній рівень “Licence" готує студента до початку професійної діяльності та водночас до подальшого навчання [11]. Ця постанова формалізує, з одного боку, зв'язок “навчання-дослідження”, який повинен дозволити студенту розвинути критичне мислення та набути спосіб міркування, адаптований до його спеціальності, а 3 іншого - пояснює подвійну функцію диплома: інтеграція до ринку праці та можливість продовження навчання. На цій підставі, за допомогою "Рамок компетентностей для спеціальностей рівня “Licence” [11], визначаються цілі навчання, очікувані компетентності, що мають буги набугими студентами підчас навчання. “Рамки компетентностей для спеціальностей рівня “Licence" $є$ основним елементом взаємозв'язку навчання 3 професійним світом. Вони 


\section{МЕТОДОЛОПІЧН АСПЕКТИ ФОРМУВАННЯПРОФЕСІЙНОӤ КОМПЕТЕНТНОСТІ МАЙБУТНІХ ЮРИСТІВ В УНІВЕРСИТЕТАХ ФРАНЦІЇ}

переглядаються що п’ять років комітетом при Міністрі з питань вищої освіти для повної відповідності вимогам ринкупраці. Освітній рівень "Licence" спирається на загальнонаціональні цілі, визначені “Рамками компетентностей”, де перелічено предметні, мовні, трансверсальні та перед-професійні компетентності, що їх має набути особа, що володіє дипломом освітнього рівня “Licence”. "Рамки компетентностей для спеціальностей рівня "Licence” від 2012 року визначає компетентність, як “доведену здатність застосовувати організовану сукупність знань, вмінь та настанов, що дозволяє здійснити певну кількість завдань" [11]. Таке визначення вказує

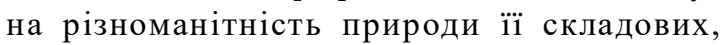
інтеграцію набутих властивостей для того, щоб компетентність існувала та існування контексту, що характеризує застосування цих набутих властивостей. Щодо різноманітності, можна 3 упевненістю стверджувати, що жодна компетентність не складається з одного типу ресурсів (засобів, щоб діяти). Потрібно якнайкраще ідентифікувати ці ресурси та спосіб їх побудови, щоб компетентність легко виявлялася. Компетентності визначаються також як здатність до дії у конкретній ситуації, що припускає наявність знань, вміння та певної поведінки. Різноманітність ресурсів вимагає певного часу для їх застосування, тому компетентність не може розглядатися як результат закінчення певного навчального курсу чи предмету. Навпаки, йдеться про сталу сукупність результатів, яка є наслідком довгої і різноманітної роботи протягом усього навчального рівня "Licence". Кожна складова компетентності повинна бути інтегрованою, а не просто накладеною на попередню. Кожний елемент формування компетентності тісно пов'язаний із іншими елементами, таким чином компетентність мобілізує інші, вже сформовані елементи. Контекст, як сукупність умов, за яких реалізовується чи виявляється компетентність, також є невід'ємним від поняття компетентності. Він $є$ певним викликом для навчального процесу, оскільки засвідчення наявності компетентності може відбутися тільки у контексті і $\dddot{1}$ підтвердження поза контекстом буде умоглядним. Впровадження "Рамок компетентностей” $\epsilon$ способом вийти із цієї зони гіпотетичності. Контекст необов'язково $\epsilon$ професійним (оцінювання відбудеться лише у реальній робочій ситуації), точним (вища освіта формує широкі компетентності), але має буди відтворюваним та контрольованим. Контекст повинен бути ретельно обраний і доступний і навчальних умовах, оскільки будучи занадто вузьким, він не дозволить реалізацію компетентності в масштабі рівня "Licence", занадто широкий - не дозволить оцінити рівень сформованості компетентності, суто професійний контекст не відповідає умовам початку вищої освіти ("Licence”). Диплом про вищу освіту рівня "Licence" (бакалавр) підтверджує набуття знань, які складають наукову, методологічну, технічну та культурну базу, що $є$ необхідною для продовження навчання на рівні "Master" (Магістр) або для початку професійної діяльності. Така база полягає в основних i суміжних предметних компетентностях, що дозволяють роботу із проблематикою, властивої для даної галузі знать через мобілізацію наукових концептів, використання теоретичних баз, методів та технік. Ці компетентності дозволяють включити дослідження до побудови знань. Загальні компетентності, сформовані в середині навчального курсу і властиві саме цьому рівню вищої освіти, а саме перед-професійні компетентності, що дозволяють виявити потенційне поле застосування набутих знань, умінь та навичок в середині даної професійної галузі, створити професійний проект і ідентифікувати навчальні курси, що дозволять реалізувати цей проект; та трансверсальні компетентності, що підтверджують здатність до самостійної роботи та аналізу, здатність брати участь у спільних проектах, здатність до критичного мислення та вправної міжособистісної комунікації, чи то шляхом спілкування французькою професійною мовою, чи принаймні однією із іноземних. Цей перелік доповнюється сукупністю наукових, методологічних та технічних компетентностей, сформованих протягом трьох років підчас типового навчального курсу. Для навчального рівня "Licence” спеціальності "Право" перелік компетентностей $є$ наступним: до предметних компетентностей відносимо вміння визначати у юридичному тексті фундаментальні концепти внутрішнього, європейського та міжнародного права та вміння їх розмістити в історичному вимірі; вміння вправно користуватися засадами юридичного аналізу для читання юридичних текстів, рішеннь юстиції, вміння ідентифікувати правові норми, що можуть бути застосовані, юридичну кваліфікацію фактів і умови контролю; вміння визначати місце права осіб, підприємств, адміністрацій та їх персоналу у політичному, економічному та соціальному контексті; вміння використовувати основні бухгалтерські, фінансові та податкові норми, що можуть бути застосованими до підприємств, адміністрацій та держави; а також ідентифікувати у документі 


\section{МЕТОДОЛОГІЧНІ АСПЕКТИ ФОРМУВАННЯПРОФЕСІЙНОӤ КОМПЕТЕНТНОСТІ МАЙБУТНІХ ЮРИСТІВ В УНІВЕРСИТЕТАХ ФРАНЦІЇ}

способи юридичного врегулювання конфліктів (скарги до адміністративних установ, посередництво, медіація, суди). До передпрофесійних компетентностей належать вміння визначати та розміщати свою роль та функції в середині організації, щоб адаптуватися та проявляти ініціативу; вміння ідентифікувати процес створення, поширення та оцінювання знань; повага до етичних принципів, принципів професійної етики та до навколишнього середовища; вміння працювати як в команді, так і самостійно та проявляти відповідальність на користь професійному проекту; вміння ідентифікувати та виявляти професійне поле діяльності, пов'язане із спеціальністю диплома та можливі шляхи досягнення успіху у цій сфері; вміння характеризувати та цінувати власну ідентичність, свої компетентності та власний професійний проект в залежності від контексту; а також багатовимірне бачення ситуації, вміння адекватно оцінити себе та переосмислити свою діяльність, щоб успішно навчатися. Трансверсальні та мовні компетентності включають вміння використовувати необхідні інформаційні та цифрові засоби, знати правила цифрової безпеки, щоб здобувати, опрацьовувати, створювати та розповсюджувати інформацію та співпрацювати в середині та назовні організації; вміння ідентифікувати та обирати різні спеціалізовані ресурси щоб підтверджувати документальними даними предмет свої діяльності; вміння аналізувати та синтезувати дані для їх подальшого використання; вміння створити відповідну аргументацію, спираючись на здатність критично мислити; вміння вправно використовувати різні стилі та регістри усного та письмового мовлення французькою мовою; розуміння на достатньому рівні та вміння висловлюватися усно та письмово принаймні однією іноземною мовою [12].

Навчання для здобуття диплом рівня "Master" (магістр) для спеціальностей у галузі міжнародного права відбувається зазвичай на базі диплому рівня "Licence" зі спеціальності “Право”. На рівні “Master" відбувається розподіл на професійну та дослідницьку магістратуру. Відповідно і компетентності, сформовані по завершенні цього навчального рівня відрізняються. Наприклад, навчання на рівні “Master", спеціальність "Міжнародне публічне право" у дослідницькій магістратурі має на меті підготувати фахівців, що зможуть продовжувати науково-дослідницьку діяльність уаспірантурі, але також і працювати у міжнародних організаціях світового та регіонального рівнів, неурядових організаціях, згодом у дипломатичних установах тощо. Тому основними компетентностями таких випускників $є$ здатність до синтезування інформації та академічного письма, здатність опрацьовувати справи по міжнародним правовим спорам, вміння представляти справу усно, вміння захищати справу у суді, розуміння цілей та засобів їх досягнення, викликів у міжнародному масштабі. Йдеться про підготовку спеціалістів, які, не зважаючи на сферу їх майбутньої професійної діяльності (дослідницьку чи практичну), будуть здатні використати основні знання та застосувати відповідну методологію для вирішення складних професійних задач у сфері приватного та публічного міжнародного права. Навчання на рівні “Master”, спеціальність "Міжнародне публічне право” упрофесійній магістратурі формує наступні компетентності: загальні та актуальні знання у галузі міжнародного приватного та публічного права, а також відповідні знання у численних предметних полях цієї спеціальності; розуміння взаємодії між міжнародним, національним (внутрішнім) та європейським правом; здатність спілкуватися усно та письмово у аргументований та документально підтверджений спосіб на теми, що належать до проблематики міжнародного приватного та публічного права; методологічна точність у використанні документальних ресурсів у міжнародному приватному та публічному праві; вміння, що визначають власника диплома рівня "Магістр" як компетентного співрозмовника та діяча у галузі міжнародного приватного та публічного права.

Висновки та перспективи подальших досліджень. Проведений аналіз наукових, психолого-педагогічних, методичних публікацій 3 проблеми дослідження та нормативних джерел, що регламентують освітній процес в вищих навчальних закладах Франції засвідчує, що компетентнісний підхід до навчання знайшов своє застосування у підготовці французьких юристів, яка має багатолітню історію, але водночас відрізняється актуальними підходами і інноваційними методами у навчанні. Довід впровадження такого підходу у вищій освіті, що грунтується на формуванні у студентів компетенцій, і професійної компетентності як наслідок, є актуальним і для українських вищих навчальних закладів. Професійна компетентність юриста поєднує дуже різні знання, вміння та навички, а прийняття українською вищою освітою європейських освітніх стандартів передбачає застосування компетентністного підходу і у навчанні українських студентів юридичних спеціальностей. Предметом подальших 


\section{МЕТОДОЛОГІЧНІ АСПЕКТИ ФОРМУВАННЯПРОФЕСІЙНОӤ КОМПЕТЕНТНОСТІ МАЙБУТНІХ ЮРИСТІВ В УНІВЕРСИТЕТАХ ФРАНЦЇ̈}

досліджень є розробка моделі формування стратегічної компетентності як складової професійної компетентності майбутніх юристівміжнародників в університетах Франції.

\section{ЛІТЕРАТУРА}

1. Антонюк Л.Л., Василькова Н.В. та ін. Компетентісний підхід у вищій освіті: світовий досвід. Київ, 2016. 66 с.

2. Гусарєв С.Д., Тихомиров О.Д. Юридична деонтологія. Основи юридичної діяльності: теоретичні, практичні та деонтологічні аспекти. Навчальний посібник. Київ, 2005. 655 с.

3. Захарченко В.М., Калашнікова С.А., Луговий В. І. та ін. Національний освітній глосарій: вища освіта. Київ, 2014.100 с.

4. Крупський Я.В., Михалевич В.М. Тлумачний словник з інформаційно-педагогічних технологій. Вінниця, 2010. 72 с.

5. Левитан К.М. Юридическая педагогика. Москва, 2007. 425 с.

6. Пометун O.I. Теорія та практика послідовної реалізації компетентісного підходу в досвіді зарубіжних країн. Київ, 2004.112 с.

7. Равен Д. Компетентность в современном обществе: выявление, развитие и реализация Москва: 2002. 396 с.

8. Хміль О.В. Особливості системи вищої освіти у Франції. Молодь і ринок, №9 (68). 2010. C.95-99.

9. Le Bofert G. Ingénerie et évaluation des compétences. Paris. 2004. 563 p.

10. Dondero B. Droit 2.0. Apprendre et pratiquer le droit au XXIe sičcle. Paris. 2015. 509 p.

11. URL: http://www.legifrance.gouv.fr

12. URL: Les référentiels de compétences en licence:http:/cache.media. enseignementsuprecherche.gouv.fr

\section{REFERENCES}

1. Antoniuk, L. \& Vasylkova, N. (2016). Kompetentnistnyj pidhid $u$ vychij osviti [Competence approach in higher education: world experience]. Kyiv, 66 p. [in Ukrainian].
2. Husarev, S. \& Tihomirov, O. (2005). Yurydychna deontolohia. Osnovy jurydychnoji dijalnosti: teoretychni, praktychni ta deontolohichni aspekty. Navchalnyj posibnyk [Legal Deontology: basics of legal activities: theoretical, practical and deontological aspect. Manual]. Kyiv. 655 p. [in Ukrainian].

3. Zahartchenko, V., Kalachnikova, S. \& Luhovyj, V. (2014). Natsionalnyy osvitniy glossariy: vycha osvita [National educational glossary: higher education]. Kyiv. 100 p. [in Ukrainian].

4. Krupsky, Ya. \& Myhalevytch, V. (2010). Tlumachnyy slovnyk $z$ informatsiynopedagogichnyh tehnolohiy [Dictionnary of informational and pedagogical technologies]. Vynnytsia. 72 p. [in Ukrainian].

5. Levitan, K. (2007). Yuridicheskaya pedagogika [Legal Pedagogy. Manual]. Moscow. 425 p. [in Russian].

6. Pometun, O. (2004). Teoria ta praktyka poslidovnoi realisatsii kompetentnistnogo pidhodu $v$ dosvidi zarubignykh kraiin [Theory and practice of successive realization of competence approach in experience of foreign countries]. Kyiv. 112 p. [in Ukrainian].

7. Raven, J. (2002). Kompetentnost v sovremennom obchestve: vyiavlenie, razvitie $i$ realizatsia [Competence in Modern Society: Its Identification, Development and Release]. Moscow. 396 p. [in Russian].

8. Khmil, O.V. (2010). Osoblyvosti systemy vychoi osvity u Francii [Features of the higher education system in France]. Yoth and market. No.9 (68), pp. 95-99. [in Ukrainian].

9. Le Bofert, G. (2004). Ingénerie et évaluation des compétences [Engineering and estimation of competencies]. Paris. 563 p. [in French].

10. Dondero, B. Droit 2.0. Apprendre et pratiquer le droit au $X X I^{e}$ sičcle [Learn and practice law in the 21 st century]. Paris. 509 p. [in French].

11. Available at: http://www.legifrance.gouv.fr

12. Available at: http://cache.media. enseignementsuprecherche.gouv.fr

Стаття надійшла до редакції 19.04.2019

\section{G58080}

"Найближиий розгляд історіӥ переконує нас у тому, що дій людей випливають 3 їхніх потреб, їхніх пристрастей, їхніх інтересів... I лише вони відіграють головну роль".

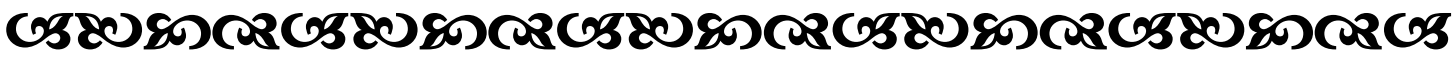

